\section{Dr. Louis Martin}

By the death of Dr. Loujs Martin on June 13, one of the last remaining lintks with Pasteur has been severed. Martin 1864. In 1892 , when he as a young doctor at the hospital for children's dyeases in Paris, he became associated with Rqux in a remarkable series of investigations which the immense possibilities of the newly docoved antitoxin for the control and treatment of diptheria. The results of their work were communicated at an International Medical Congress at Budapest in 1894 by Roux, Chaillou and Martin in a paper the importance and high quality of which has been recognized for half a century. This was Martin's introduction to diphtheria, a subject in which his interest remained unabated to the end of his life. He was appointed to the staff of the Pasteur Institute in 1892, where he remained for the rest of his working life, occupying positions of increasing importance and finally becoming director in 1934. He made notable contributions to the bacteriology of the diphtheria bacillus and closely related organisms, devised a culture medium for the production of diphtheria toxin which is widely used to-day, extended his researches on the prophylaxis and treatment of diphtheria, and studied the problems presented by the 'carrier'. For many years he was responsible for the production of the antitoxins and antisera required in France, and later he found solutions to the technical and administrative problems created by the enormously increased demand for these materials during the First World War.

Martin was also interested, and experienced, in public health problems and in the construction and organisation of infectious diseases hospitals. His advice was constantly sought by the State Department and by municipalities concerning the control of epidemics; and the Pasteur Hospital, which Martin served sinee its establishment in 1900, gave him the opportunity for studying, under what were then novel conditions, the medical care and nursing of cases of infectious disease. With Brouardel he wrote a treatise on hospital organisation and the prophylaxis of infectious diseases, which is a standard work on this subject in France.

In 1914, Martin became vice-president of the Society of Biology and, in later years, president of many learned societies. In 1919 he became a member of the Academy of Medicine and in 1937 he was elected to the Academy of Sciences. Martin's somewhat forbidding appearance and brusque manner hid a warm, kind and generous nature. He gave a lifetime of high endeavour to the service of science, to France, and to the Institute he loved so well.

Percival Harthey

86

Mr. G. H. J. Adlam, O.B.E.

Mr. G. H. J. ADLAM, editor of the School Science Review, died suddenly on July 30 . With his passing a great lavdmark has gone, for he alone of the officers of the cuase Masters' Association was re-elected year after year, so that members came to look upon hiph as a permanent pillar of the Association. His was the thought that first suggested the School Science Review and his the guiding hand that led it to success. As time went on, zeal for the welfare of the Review grew upon him and gripped him more and more until it became his ruling passion. When at the age of sixty-seven he retired from his school duties, having with indifferent health courageously carried on during the War, he looked forward to his leisure to make the Review even better. Already in his hands the 1919 booklet of thirty-two pages had in a few years become the largest and most influential journal of school science in Great Britain, if not in the world. Undoubtedly Adlam did more for the betterment of school science than any man of his generation: the value of his work is incalculable. Such an achievement could not pass unnoticed and in 1934 Adlam was awarded the O.B.E. Later, in 1941, he became president of the Science Masters' Association.

Adlam was educated at Wells Cathedral School and Wadham College, Oxford. He graduated with firstclass honours in chemistry, and later obtained his B.Sc. for research work on the water component of systems of hydrated salts. He was the editor of the Science Masters' Association publications and the author of some widely used text-books of chemistry. After a varied teaching experience, he settled down at the City of London School, where for many years he was in charge of the science.

"Joe" Adlam, shy and kindly, was in school and on committee an admirable colleague, sage in counsel and sound in judgment. At this critical time in educational affairs his advice and lead will be sorely missed. Qualified as a man of science, he was also an accomplished English scholar, with a rich humour and a rare aptitude for finding the appropriate word. To many a diffident young author he was extraordinarily kind, suggesting better arrangements of his subject-matter and not infrequently re-writing an entire article. In all his activities, his standards were high. He had a dread of losing grip and rusting away; but he died as he wished, in the midst of useful work -he had just completed the third volume of Physics in the Science Masters' Book.

All who knew Adlam will lament his death and extend their sympathies to his widow, formerly Florence Lavinia Chun. A charming hostess and capable housekeeper, she shared his enthusiasm for his favourite recreation-the cultivation of his rock plants-and did much to cheer the evening of his life.

G. Fowles

\section{Dr. L. B. C. Cunningham}

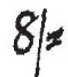

Dr. Leslie Benngri Crajdor Cunningham died at Harrow on August 3f ath the fage of fifty-one. Although seriously ill for $A$ isthy period prior to his death he continugd, fotil the last few weeks, to evince the keengst in tertst in the research problems of air armaponts to which his life's work was devoted.

B $\mathrm{yh}^{\mathrm{h}}$ of Scots parentage, Cunningham was educated at Edinburgh Academy and Sedbergh School. His career at the University of Edinburgh was interrupted by the First World War, in which he was commissioned in the King's Own Scottish Borderers and later transferred to the Royal Engineers (Signals Service). On the completion of his studies at Edinburgh he was appointed as an education officer in the R.A.F. and served at No. 1 Air Armament School at Eastchurch and. later Manby. In this post his work ranged over the whole theory of air armament both in instruction and research. In 1931 the twoyear advanced armament course of university standard was inaugurated under his technical direction, and all senior present-day R.A.F. armament officers were at one time Cunningham's pupils, many 
consulting him regularly throughout the Second World War. During this period he was awarded the Ph.D. of the University of Edinburgh for his work on bomb ballistics.

At the outbreak of the Second World War, Cunningham was appointed by the Director of Scientific Research, Air Ministry, to lead a small body of research workers in the development and application of a mathematical theory of air combat which he had earlier produced. The scope of the work of this group, called the Air Warfare Analysis Section, and its strength, expanded rapidly during the War until it eventually covered a very wide field, ranging from the geodetic work associated with the blind-bombing tactics of the R.A.F. to the statistical theory of aimwander in aerial gunnery.

In 1945 Cunningham was elected a fellow of the Royal Society of Edinburgh. Security restrictions unfortunately prevented the publication of much of his work, but a joint paper with W. R. B. Hynd on the application of the theory of random processes to air-warfare, read recently before the Royal Statistical Society, indicates the trend of much of his recent work.

Cunningham was prevented by his death from taking up a high appointment at the Royal Aircraft Establishment, Farnborough, and his loss will be keenly felt throughout the sphere of air armaments. $\mathrm{He}$ will be remembered with affection by all who worked with him.

E. C. CORNFORD

\section{WE regret to announce the following deaths :}

Sir Carruthers Beattie, during 1918-37 vicechancellor and principal of the University of Cape Town, on September 10, aged seventy-nine.

Sir James Jeans, O.M., F.R.S., on September 16, rged six ty-nine.

Nikolai Morozov, honorary member of the Academy of Sciences of the U.S.S.R., known for his general writings on scientific topics, on July 13, aged ninetytwo.
$81=$

Engineering at Edinburgh: Prof. R. N. Arnold

Prof. R. N. Arnowd has been appointed to the regius chair of engineering in the University of Edinburgh. How. Arnold completed a brilliant studentship robord by graduating at the University of Gasgow 1932 with first-class honours, and followed th Apetly with a period on research, which qualified hif $\mathrm{f}_{\mathrm{f}} \mathrm{r}$ the associateship of the Royal Technical College and won the principal College research award. Appointment to a Senior Caird Scholarship then followed, and with this, he went to Sheffield to continue his work on engineering materials in Prof. Lea's laboratory. This phase of his research career was notable for work on embrittlement, the theme of several important papers and the subject of his thesis for the Ph.D. degree. In 1934 he accepted appointment to a Commonwealth Fund Fellowship and spent the two succeeding years at the University of Illinois. His work there was marked by a significant change from the more static type of materials investigation to the dynamical questions of impact and vibration; and his later publications have demonstrated his interest and power in this field.

On his return from Illinois in 1936, Dr. Arnold was appointed to a lectureship in the Department of Civil and Mechanical Engineering in the Royal Technical College, Glasgow, where in addition to a wide range of teaching, he took a prominent part in the special investigations conducted by the department. His work on the topical engineering problem of the 'singing propeller' was particularly valuable, and the papers published by him and his colleagues on this subject aroused considerable attention and gained the Gold Medal of the Institute of Engineers and Shipbuilders in Scotland and the Thomas Lowe Gray Prize of the Institution of Mechanical Engineers. In 1941, Dr. Arnold joined the senior staff of the Metropolitan-Vickers Electrical Co., and while there was engaged on many important investigations. Later pepers on some of these have made him widely known as a main authority on such diverse lines as machine tool dynamometry and gyroscopic stabilization problems. The latter was the subject of his thesis for the Glasgow D.Sc., which gave a fine

\section{nd VIEW S}

demonstration of analytical and experimental powers, adequately and successfully combined with inventive faculty and design capacity. He was appointed professor of engineering at University College, Swansea, in 1944, and leaves this position to succeed the late Sir Thomas Hudson-Beare at Edinburgh. Scottish engineering will welcome his return. He brings a fine teaching experience and real gifts of exposition to the instruction of its students, and a proved and polished research power to aid its development.

Geology at University College, London : Prof. S. E. Hollingworth

Dr. S. E. HoLlugworth has been appointed to the Yates-Goldsmidv chair of geology in University College, Lgpdo hrun leaving Cambridge, Dr. Hollingworth joired the Geological Survey in 1921 and went to the Cumbrian unit then based on Whitehaven. $\mathrm{He}$ took part in the survey of the Whitehaven, Gosforth, Cockermouth and Brampton sheets. In Whitehaven and Gosforth he was concerned mainly with Borrowdale rocks and with the Ennerdale Granophyre, but had some Carboniferous rocks with hæmatite. In the Cockermouth Sheet he was allotted the area including the Carrock Fell Complex, made classic by Harker, the greisen mass (with tungsten deposits) of the Skiddaw Granite and the metamorphic aureole of Skiddaw Slates, the Eycott and the northern area of Borrowdales with the Caldbeck mining field, mainly derelict but including the barytes deposit of Potts Ghyll. Much of this work is as yet unpublished, but marks an advance on that of previous workers. In the Brampton area he was concerned mainly with Lower Carboniferous strata and Triassic rocks with gypsum. Here he became particularly interested in drift deposits which led to his paper on glaciation in Western Edenside (Quart. J. Geol. Soc., p. 281, 1931), which was accepted for D.Sc. London. On the dispersal of the Cumbrian unit, Dr. Hollingworth was sent to the Droitwich area, mainly on Trias, and later to that around Cambridge, with its widespread Drift and Recent deposits. At the outbreak of war it was essential that assistance from the Survey should be fortheoming on home ore deposits, 